\title{
Policy Support for Developing Green Economy and Promoting the Construction of Ecological Civilization
}

\author{
Lv Jinfang, Qin Shusheng \\ Marx School of Northeastern University
}

\begin{abstract}
Development of green economy is an important way to promote the construction of ecological civilization which needs the support of policy system. Therefore, our country should make the green industry and green fiscal policy supporting system perfect, accelerate the reform of investment and financing mechanism, and improve the system of green finance policies. Only by establishing scientific green economic policy support system, can our country promote the construction of ecological civilization.
\end{abstract}

Keywords: green economy, ecological civilization, policy

With the acceleration of China's industrialization process, the emission of pollutants has greatly exceeded the environment capacity, and the ecological environment is facing enormous challenges and pressures. Nowadays, ecological problems have become the bottleneck restricting the development of the country. In order to solve these problems, China should further develop the green economy and promote the construction of ecological civilization vigorously. Ecological civilization is a kind of civilization form characterized by industrial ecologicalization. And developing green economy is an important way for the establishment of the ecological civilization. Green economy is a new form of economy composed of three important elements including ecology, environment, and resource. It is market-oriented and based on industrial economy. With the support of scientific and technological innovation, it aims to develop the economy, society, and ecology harmoniously, maintain the human living environment, exploit and utilize the resources scientifically, and coordinate the relationship between human and nature.

The development of the green economy and the promotion of the construction of ecological civilization require not only that the enterprises change their economic development mode and establish a new green development pattern, but also that the government creates a favorable policy environment for those businesses to develop green economy. Such supporting policies include industrial policy, finance and taxation policy, monetary policy, and so on. The construction of ecological civilization is a long process, which needs a scientific, standardized, long-term, and stable policy support system to promote green development, the coordinated development of the economic society, and ecological environment as well as the sustainable use of resources. Thus, our country can speed up the process of the construction of ecological civilization.

Lv Jinfang, Ph.D., Dr., Marx School of Northeastern University, China; main research field: Marxist Ecological Principle.

Qin Shusheng, Ph.D., professor, Marx School of Northeastern University, China; main research fields: Marxist Ecological Theory and Ecological Philosophy. 


\section{Improving the Green Industrial Policy}

The traditional way of "governance after pollution" is not feasible any more. Our country should focus on the coordinated development of the economy, society, and the ecology. As more and more people become aware of green development, green consumption and the demand for green products will increase sharply, creating favorable conditions for the development of green industry which helps to realize a transformation from an extensive economic development mode to a sustainable and recyclable one and further promote the construction of the ecological civilization. Thus, an industrial structure policy should be made in line with the requirements of ecological civilization, so as to provide necessary policy support for green industry.

\subsection{Adjusting the Internal Structure of the Industry to Optimize and Upgrade the Industrial Structure}

Currently, industrial structure in China is not perfect. The structures of light and heavy industries are imbalanced and are under rapid changes. So, it is necessary to adopt appropriate policies to guide and promote industrial restructuring within the industry, so as to promote the optimization and upgrading of industrial structure and the development of green industry. Therefore, something should be done in the following aspects: encourage the production and utilization of the consumer goods with good performance in energy conservation and low environmental pollution emission to form energy-saving and green consumption patterns. Besides, our country should develop the green industry vigorously, improve the relevant policies and measures, and encourage and support the techniques, equipments, and products which contain high technology and are conducive to the improvement of energy efficiency, the development, and utilization of new energy and renewable energy, as well as energy conservation and environmental protection. Our country should restrict the backward techniques, equipments, and products which are not beneficial to structural optimization, energy conservation, and environment pollution, and gradually weed out those which consume too many resources and endanger safe production.

\subsection{Investing More Green Technology Innovation to Promote the Development of Green Industry}

Scientific and technological progress is the decisive factor to realize the harmonious development between human and nature in our country. Green technology should be applied continuously to improve the energy efficiency, and reduce the energy consumption and pollution emissions in secondary and tertiary industry. At present, our country should focus on strengthening the research and utilization of low carbon technology, alternative energy development technology, clean production technology, waste recycling technology, environmental pollution and control technology, ecological environment monitoring, and so on, so as to promote the development of green industry and accelerate the process of ecological civilization construction. Therefore, the government should support the basic research and technical development of green industry, and increase capital investment in R\&D of green science and technology innovation, so as to promote the R\&D and investment of the green technology in enterprises, and promote the optimization and adjustment of industrial structure, and the optimization and adjustment of industrial structure.

\section{Improving the Green Financial Support System}

Fiscal policy is an important tool and means of macroeconomic regulation and control, which plays an important role in promoting and guiding the construction of ecological civilization. In recent years, although 
our country has increased investment in the construction of ecological civilization, the current forms and means to support ecological civilization construction are not perfect. Therefore, our government should strengthen the fund investment in the construction of ecological civilization and the improvement of the policy system, and determine the proportion of the investment in ecological civilization construction within a certain period of time so as to build up a stable fund input mechanism of ecological civilization construction.

\subsection{Improving the Green Budget System}

Budget system, as the government's annual plan for revenue and expenditure, is the primary means of fiscal policy. And it is an important tool for government macro-control. To improve the green budget system, the budget structure needs to be adjusted and the special funds should be established for ecological civilization construction to ensure a steady investment in the construction of ecological civilization. By adjusting the green budget revenue and expenditure structure, our country should increase the financial investment in energy conservation, enhance its proportion in the investment budget, increase the financial investment in the ecological industry, and encourage the development of ecological industry. Meanwhile, the country should reduce the funds supply to the enterprises with high input, high pollutant emissions, and low output to limit their development.

\subsection{Establishing the Green GDP Accounting System}

Chinese traditional GDP accounting only focuses on the rise of the economic output, regardless of the resources and environmental costs, resulting in the uncoordinated development between the economic development and ecological environment. Therefore, our country needs to build green GDP accounting system. Green GDP is a way of self-examination to the past crude mode of development with high energy consumption, high pollution, and low output. Directed by such system, resources, environment, and economy in the economic activities are integrated in a comprehensive accounting. The costs of resource depletion and environmental pollution are deducted from the current total GDP so as to scientifically reflect the development level of Chinese economy and society as a whole. The establishment of green GDP accounting system is conducive to the transformation of Chinese economic development mode and the realization of the coordinated development of economy, environment, and society. However, the current green GDP accounting system in China is still imperfect, such as shallow understanding, imperfect mechanism, backward accounting technology and weak practicality, and the like. In order to make the green GDP accounting play its role as soon as possible, our country must make it standardized and institutionalized. And a scientific and effective method to calculate the value of resource cost and social cost is the key to improve the GDP accounting system. Therefore, relevant departments should develop scientific and unified green GDP accounting standards and accounting methods as soon as possible.

\subsection{Improving the Green Procurement System}

There are still some drawbacks in Chinese green procurement system, such as the narrow scope of procurement etc. Thus, our country should speed up the legislative progress for government procurement of green products, expand the procurement scope, and improve the certification system of environmental protection product.

2.3.1. Establishing the Standards for Green Procurement

Green procurement standards are the prerequisite for the effective implementation of green procurement. It 
is necessary to learn from the experience and methods of green procurement from the developed countries, so as to improve the existing inventory system and ensure the green characteristics of the list. What's more, our country should establish the performance evaluation criteria of green procurement, clarify the performance appraisal rules, and establish the performance evaluation mechanism, so as to maintain the rationality and sustainability of green procurement funds.

\subsubsection{Establishing Good Information Communication Mechanism}

The cultivation of the awareness of green purchasing throughout the whole society and the enhancement of the social recognition of green procurement and development of good information communication mechanism help to promote the government green procurement smoothly. Consequently, our country has to intensify the publicity and education of green procurement, cultivate people's awareness of green procurement, and announce the information about the price and the quality of the products obtained through green procurement, so as to enhance social support of green procurement.

\subsection{Improving the Green Tax System}

Currently, our tax policy lacks an independent ecological environment protection tax and the preferential tax policy is not perfect. So, our country need establish and improve the green tax system.

\subsubsection{Adjusting and Improving the Existing Resource Tax}

First, our country must expand the scope of resource tax. On the one hand, China should expand taxation range to involve water, ocean, wetlands, grasslands, forests, and other natural resources. Meanwhile, all kinds of resource fees will incorporate into the resource tax, realizing the unification of resource tax and fee. On the other hand, China should enhance the standards for tax collection. Our country needs to improve the pricing mechanism of resource products by raising the prices of resource-based products and the unit tax according to the degree of scarcity of the products, so as to promote enterprises and individuals to conserve resources and improve the resource utilization.

\subsubsection{Necessity to Collect Environmental Taxes in China}

Through environmental tax, the country could internalize the environmental pollution and the social costs of ecological destruction into the production costs and market prices, and then allocate environmental resources through the market mechanism. Environmental tax will inevitably affect the tax burden of polluting enterprises, change their cost and income ratios, and force them to reevaluate the efficiency of the resource allocation. Therefore, environmental taxes will not only contribute to environmental governance, but also help the enterprises to improve the process and increase technological innovation, which, to a certain extent, helps to enhance their competitiveness. At present, our country will begin to levy ecological protection tax on some natural resources as an ecological compensation for the destruction of resources and environment they have brought.

So, starting to levy carbon tax can encourage enterprises to increase the low carbon technology innovation and reduce carbon dioxide emissions and environmental pollution.

\subsubsection{Increasing Tax Incentives to Support the Development of Environmental Protection Industry}

The preferential policies of environmental protection tax can stimulate enterprises to improve technology, control environment pollution, develop green economy, and enhance their comprehensive strength. Our government should further increase tax incentives, reduce or remit income tax of environmental protection enterprises, and exempt or refund two taxes from sewage and garbage disposal enterprise immediately. 


\subsection{Improving the Policies of the Emission Trading Market}

The related policies about emission trading are in backward status, and there are a lot of problems, such as the imperfect total control and environmental supervision mechanism, inactive emission trading and too high transaction cost. Emission trading refers to a system of free trading of emission rights through market mechanism under the premises that the control targets of the pollutant emission from all sources are clearly determined.

According to the principle of "those who developed should protect the environment and those who get benefits should make compensation," our country should establish and improve the charging system on waste and sewage discharge as soon as possible, introduce the market mechanism in the emissions trading market mechanism, change the way of pollution abatement from government enforcement into an autonomous market behavior of enterprises, and encourage enterprises to practice energy saving and emission reduction by using economic leverage. Emissions trading system not only contributes to enhancing the enthusiasm and initiative of enterprises to deal with pollution, but also helps to promote enterprise energy conservation, emission reduction, and environmental protection, paving the way for the construction of ecological civilization.

At present, urgent measures should be taken from two aspects in order to improve the system of emissions trading rights: First, China should improve the legal system of total amount control and provide legal support. Legislation should be made as soon as possible, stipulating the control system on the total amount of pollutants and relevant scientific approaches should be enacted at the same time, which could provide a legal basis and operability for making and implementing proper relevant policies. Second, the country should reduce the transaction costs of emission rights. By building an open market, increasing transparency of transactions and establishing emissions trading intermediaries, our country could minimize transaction costs of emission rights effectively.

\subsection{Developing and Implementing a Deposit-Refund System}

In recent years, deposit-refund system has been used widely as an important means of inhibiting solid waste pollution in developed countries. Implementation of this system, helps to improve the recovery and utilization rate of products, saves resource, and reduces pollutant emissions effectively. In such cost deposit-refund system, the consumers have to pay a certain amount of fees for those products which may endanger the environment. If these products are recycled and the remnants are sent to designated collection places as required, the deposit could be sent back to the consumers. At present, our country has not yet developed a deposit-refund system. But the government can learn from foreign experience to develop and implement the system to guide the businesses and consumers to recycle solid waste, conserve resources, and reduce pollution.

\section{Improving the Policy System of Green Finance}

The construction of ecological civilization involves great financial support, and the government cannot meet the financial requirements by itself. Therefore, the investment and financing channels should be broadened and a comprehensive and diversified investment mechanism, in which the governmental financial investment plays the major role, should be established to guarantee a smooth construction of ecological civilization. Our country should accelerate the reform of the market system and improve the incentive policies to attract more social and foreign financial investment in the construction of ecological civilization and promote its rapid development. 


\subsection{Establishing the Special Investment Fund for Ecological Civilization Construction}

Fund is the key for ecological civilization construction. So our country should build a diversified, long-term, and stable financial investment guarantee mechanism to solve the problem of the money shortage. And the financial sector of the government should allot special fund out of budget and provide constant financial support for ecological civilization construction. It is important to raise a lot of money from the community, encourage and lead the capital flow to the field of ecological civilization construction, and give priority to the development of ecological enterprises and projects in the allocation of the industrial investment fund. Meanwhile, an effective supervision mechanism for the earmarking fund should be built to ensure the efficiency of using investment funds.

\subsection{Improving the Green Credit Policies}

Green credit policy is to reduce or ban offering loans to the polluting enterprises and provide financing support for the eco-enterprises, in order to curb the resource crisis and environmental degradation. This policy is a new strategy to solve the problems of environmental degradation, which can effectively curb the development of these industries with high energy consumption, low output, and high pollution, stimulate the development of environmental protection enterprises, and promote the development of low carbon economy. Therefore, our country should establish a long-term mechanism of "credit support for energy saving and environmental protection." First of all, our country should strengthen supervision, raise the level of transparency, and improve the system of bank information disclosure. The banking industry should incorporate the factors including environment, society, and economy into its credit management and enterprise evaluation system while conducting credit-related activities. The information about the environmental and social influence of specific projects of public concern should be published timely to the public. Green credit information sharing should also be further strengthened. And their environment protection commitment as well as related loan service should be updated in time and disclosed to the public at all time. Then, the environment protection basis for bank credit will be more adequate and more transparent. Furthermore, it's important to implement the preferential loans policies to promote the development of environmental protection industry and enterprises. The government could provide preferential policies in credit for ecological industry, recycling enterprises, and green technology research and development. Meanwhile, it should offer further support to the industries with low emission and low pollution, enterprises focusing on environmental protection, and the research and development of environmental technology, while cutting the line of credit of those enterprises whose pollutant emission exceeds the standard by limiting, stopping and even taking back the loans to them, so as to promote the enterprise's independent management of the environment, improve environmental protection technology, and promote the development of our country's low carbon economy.

\subsection{Giving Full Play to the Financing Function of Financial Institutions and Providing Financing Support for the Construction of Ecological Civilization}

\subsubsection{Expanding the Direct Financing Function of the Stock Market}

Give full play to this function and accelerate the development of market-based financial system, so as to provide strong financial support for the construction of ecological civilization. Therefore, it is necessary to give priority to the listing and financing of the large-scale and high-quality eco-enterprises and lower the listing threshold to them so as to provide public financing opportunities for those eco-enterprises. Besides, great effort 
should be put into the development of small and medium-sized eco-enterprises and the acquirement of the support funds to develop the ecological civilization. It is also essential to promote the establishment and improvement of the ecological civilization growth enterprise market, and create a special ecological construction financing market, providing a sustainable source of direct funding for the ecological enterprises or specific resource type enterprises.

\subsubsection{Improving the Bank's Indirect Financing Function}

Policy based financial activities have an important influence on the construction of ecological civilization, and these activities can promote the enterprise economic benefits, ecological benefits, even social benefits as a whole. So our country should take full advantage of low-cost policy funds to support the financing of SMEs with emphasis on recycling and provide funding grants, loans interest subsidies, and other financial support for the major projects, technology development, and industrialization demonstration projects of recycling based high tech industries, which have a prominent role in ecological civilization construction.

3.3.3. Innovating Insurance Businesses and Establishing Insurance System about the Environmental Pollution Liability

Insurance plays a crucial role in social investing and financing system, which provides strong financial support for the construction of ecological civilization. Thus, our country should make innovative changes to insurance businesses and encourage insurance companies to buy or participate in the establishment of a recycling economy venture capital fund or subscribe for the stocks and bonds issued by eco enterprises.

Besides, the insurance industry has some specific functions, such as dispersing risk and bearing a special financial compensation, which determines its important role in preventing and neutralizing the risk brought by green technology development and application. In the process of constructing ecological civilization, there will be various risks. Therefore, the establishment of environmental pollution liability insurance system is an important part of risk prevention in current insurance companies. Environmental pollution liability insurance is a kind of insurance aiming at the liability which the pollutant discharging units should take in order to compensate for the damage they have caused to the third party.

Therefore, our country should improve the legislation of environmental tort in time to enable enterprises to automatically buy environmental pollution liability insurance. At the same time, improvements should also be made in the insurance way, the targets for the compulsory insurance as well as the scope of insurance liability based on the actual conditions of our country.

\section{Works Cited}

Chen, Zongxing. “Developing Green Economy and Building Ecological Civilization [J].” Advance Forum 12 (2012): 16.

Li Ning and Ding Sibao. "Establishing and Perfecting the System of the Construction Regional Ecological Compensation Mechanism in Our Country [J].” Chinese Population • Resources and Environment 1 (2009): 149.

Liu Zheng. "Culture Awareness of Ecological Civilization [M].” Shanghai: Shanghai Jiao Tong University Press, 2 (2012): 206.

Qi Meidong. “Our Country Circular Economy Research on Financial Support [M].” Hefei: Hefei University Press, 11 (2010): 185.

Xie Zhenhua and Bie Tao. "Ecological Civilization and Eco-consciousness [M].” Hangzhou: Zhejiang Education Press, 4 (2013): 291. 